\title{
Gestão por Competência na Justiça Eleitoral: implantação, benefícios e dificuldades do modelo
}

\section{Competence Management in Electoral Justice: implementation, benefits and difficulties of the model}

\author{
Lana Montezano $^{1 *}$, Bruna Menezes e Silva ${ }^{1}$
}

${ }^{1}$ Universidade de Brasília, Brasília, Brasil.

\section{INFO ARTIGO \\ Palavras-chave: \\ Gestão por Competências; Organização Pública; Justiça Eleitoral.}

\begin{abstract}
RES U M O
A Gestão de pessoas por competências tem sido adotada pelas organizações públicas com vistas à melhoria da prestação de serviços. Este artigo descreve a implantação da gestão por competências na Justiça Eleitoral com os benefícios esperados e dificuldades enfrentadas. O estudo caracteriza-se como teórico-empírico, descritivo, com recorte transversal e abordagem quantitativa e qualitativa. Os dados foram coletados com representantes de 22 Tribunais Eleitorais que atuam na implementação da gestão por competência, com aplicação de questionário eletrônico, e analisados com estatística descritiva e análise de conteúdo. Como resultados prevalecentes se teve: 16 Tribunais possuem iniciativas da gestão por competências; as principais ações adotadas são relacionadas ao subsistema de Treinamento e Desenvolvimento de Pessoal, principalmente de identificação de competências necessárias, alinhado ao aspecto considerado como principal benefício do modelo (Educação Corporativa) e como principal dificuldade a falta de apoio da alta administração e gestores. Recomenda-se novas pesquisas relacionadas a implantação da gestão por competências na esfera pública, inclusive dos efeitos nos resultados organizacionais.
\end{abstract}

\begin{tabular}{l}
\hline A R T I C L E I N F O \\
\hline Keywords: \\
Management by \\
Competencies; \\
Public Organization; \\
Electoral Justice.
\end{tabular}

\footnotetext{
* Correspondência para autor:

lanamontezano@gmail.com (Montezano,_.), bruna_menezes@hotmail.com (Silva, B.M.).
} 


\section{Introdução}

A Administração Pública vem buscando adotar mecanismos que proporcionem melhorias na qualidade, eficácia e eficiência da prestação de serviços à sociedade, sendo a implantação da gestão por competências um dos meios para viabilização deste objetivo com melhorias no desempenho organizacional (GUIMARÃES, 2000; SILVA; MELO; TORRES, 2013; GETHA-TAYLOR; BLACMAR; BORRY, 2016), por se tratar de um modelo visa traduzir a estratégia organizacional no comportamento dos profissionais que trabalham nela (CAMPION; SCHEPKER; CAMPION; SANCHEZ, 2019). A Gestão por competências vem sendo adotada em diversos países, devido a obtenção de resultados positivos em organizações públicas, decorrente da integração dos subsistemas de gestão de pessoas em uma linguagem comum (SKORKOVÁ, 2016). Este fato é materializado com a criação da Política Nacional de Desenvolvimento de Pessoal da Administração Pública Federal Direta com o Decreto 5707/2006, a qual estabelece a adoção da gestão por competências como meio para o desenvolvimento permanente do servidor público, o qual foi revogado e instituído o Decreto de 9991/2019 sobre a nova política de desenvolvimento de pessoas.

Alinhado a este contexto, o Poder Judiciário também começou a se preocupar com a implantação da gestão por competências e emitiu normativos sobre o desenvolvimento de servidores dos seus quadros, como as Resoluções TSE nº 22.572/2007 e 2.582/2007.

Apesar do estudo de revisão de literatura sobre gestão de pessoas no setor público apontar para avanços nas publicações acerca de pesquisas de gestão por competências neste cenário (BANDEIRA; ARRUDA; CABRAL; SANTOS, 2017), ainda existem lacunas que precisam de investigação quanto à realização de estudos de competências no serviço público (ARAÚJO JÚNIOR; MARTINS, 2014; GAETA; MARZANO; MIRANDA; SANDKUHL, 2017; LANDFELDT; ODELIUS, 2017; MONTEZANO; MEDEIROS; ISIDRO-FILHO; PETRY, 2019; MONTEZANO; MEDEIROS; PINHEIRO; OLIVEIRA, 2019), inclusive no contexto da Justiça (SENA; CUNHA, 2015) e mais especificamente na Justiça Eleitoral (SANTOS, 2012).

Com vistas a suprir algumas destas lacunas e para a melhor compreensão do processo de implantação da gestão por competências na Justiça Eleitoral, tem-se as seguintes perguntas de pesquisa: quais Tribunais já adotaram este modelo? O que motivou o Tribunal a adotar? Como se prepararam para desenvolver seus respec- tivos modelos? Dentre as etapas existentes em modelos da literatura, o que tem sido utilizado efetivamente por estas organizações?

Desta forma, este artigo tem como objetivo a implantação da gestão por competências na Justiça Eleitoral, bem como descrever as principais dificuldades, benefícios e possíveis ações necessárias para sua efetiva adoção.

Com isso, como contribuição, espera-se que além de preencher lacunas da literatura, o artigo possa trazer discussões quanto às barreiras, que estão limitando a efetiva implementação e apresentar sugestões de melhorias que viabilizem a adoção deste modelo para que, tanto a Justiça Eleitoral quanto outras organizações públicas, possam superá-las de modo a obter melhores resultados organizacionais com a gestão por competências.

\section{Referencial Teórico}

\subsection{Noções de competências}

Apesar dos avanços nas pesquisas de competências, Asame e Wakrim (2018) afirmam que os estudos sobre o tema apresentam diferentes abordagens e campos de aplicação, e ao analisar diferentes conceitos da literatura, apresentam as principais características da competências: refere-se a uma combinação integrada de vários recursos (conhecimentos, habilidades, atitudes, motivos, características, valores), os quais são mobilizados para execução de um trabalho em um determinado contexto com vistas ao bom desempenho.

Como este trabalho é sobre uma pesquisa no setor público, buscou-se a definição de competências que tenha sido adotado neste contexto. Montezano, Abbad e Freitas (2016, p.3) propõem como a expressão de comportamentos observáveis de resultados bem-sucedidos a partir do conjunto de conhecimentos, 
habilidades e atitudes no contexto laboral. Além disso, também foi considerada a definição apresentada no Decreto $\mathrm{n}^{\circ}$ 5.707/2006, para o contexto de organizações públicas federais, o qual estabelece como "conjunto de conhecimentos, habilidades e atitudes necessários ao desempenho das funções dos servidores, visando ao alcance dos objetivos da instituição".

As competências podem ser classificadas sob diferentes aspectos, tais como nível de análise, amplitude, especificidade e temporalidade. O Quadro 1 apresenta as classificações que subsidiaram a realização deste estudo, com as respectivas descrições e referencias.

Quadro 1 - Tipos de classificações das competências.

\begin{tabular}{|c|c|c|c|}
\hline \multirow{2}{*}{ Classificação } & \multicolumn{3}{|c|}{ Tipos de classificações das competências } \\
\hline & Tipos & Referencia & Descrição \\
\hline \multirow{3}{*}{ Quanto ao Nível } & Organizacional & $\begin{array}{c}\text { Brandão e Guimarães (2001); } \\
\text { Brandão (2009); Asame e } \\
\text { Wakrim (2018) }\end{array}$ & Associadas a missão da organização. \\
\hline & De Equipe & $\begin{array}{l}\text { Brandão (2009); Asame e } \\
\text { Wakrim (2018) }\end{array}$ & $\begin{array}{l}\text { Refere-se aos trabalhos desenvolvidos } \\
\text { pelos grupos (coletiva). }\end{array}$ \\
\hline & Individual & $\begin{array}{c}\text { Brandão e Guimarães (2001); } \\
\text { Brandão (2009); Asame e } \\
\text { Wakrim (2018) }\end{array}$ & $\begin{array}{l}\text { Refere-se aos comportamentos } \\
\text { observáveis do indivíduo e sua atuação no } \\
\text { contexto organizacional. Também } \\
\text { denominadas de humanas ou profissionais. }\end{array}$ \\
\hline \multirow{4}{*}{$\begin{array}{c}\text { Quanto } \\
\text { temporalidade }\end{array}$} & Emergente & \multirow{4}{*}{$\begin{array}{l}\text { Guimarães, Bruno-Faria e } \\
\text { Brandão (2006) }\end{array}$} & $\begin{array}{l}\text { São as necessárias à demandas que ainda } \\
\text { não são feitas e que serão necessárias no } \\
\text { futuro. }\end{array}$ \\
\hline & Declinante & & $\begin{array}{l}\text { Refere-se a que tende a não ser mais } \\
\text { necessária à organização. }\end{array}$ \\
\hline & Estável & & $\begin{array}{l}\text { São as necessárias para o desempenho das } \\
\text { atividades atuais da organização, tendo sua } \\
\text { relevância permanente ao longo do tempo. }\end{array}$ \\
\hline & Transitória & & $\begin{array}{c}\text { Refere-se ás necessárias em um } \\
\text { determinado momento para resolver } \\
\text { alguma situação pontual, como uma } \\
\text { mudança ou algo crítico. }\end{array}$ \\
\hline \multirow{2}{*}{ Organizacionais } & Básicas & \multirow{2}{*}{$\begin{array}{l}\text { Guimarães, Bruno-Faria e } \\
\text { Brandão (2006) }\end{array}$} & $\begin{array}{l}\text { Referente ao funcionamento da } \\
\text { organização como um todo para subsidiar } \\
\text { as atividades finalísticas da organização. }\end{array}$ \\
\hline & Essenciais & & $\begin{array}{c}\text { Repesentam o motivo da existência da } \\
\text { organização, a qual a diferencia de outras } \\
\text { organizações. }\end{array}$ \\
\hline \multirow{2}{*}{$\begin{array}{c}\text { Individuais quanto } \\
\text { à amplitude }\end{array}$} & $\begin{array}{l}\text { Gerais ou } \\
\text { transversais }\end{array}$ & \multirow[t]{2}{*}{ Brandão (2009) } & $\begin{array}{l}\text { São as necessárias independente da } \\
\text { atuação profissional, ou seja, que não } \\
\text { depende do cargo que a pessoa atua. }\end{array}$ \\
\hline & Específicas & & $\begin{array}{l}\text { São as necessárias dependendo das } \\
\text { atividades desempenhadas no cargo/função. }\end{array}$ \\
\hline \multirow{2}{*}{$\begin{array}{c}\text { Individuais quanto } \\
\text { à especifificade }\end{array}$} & \multirow{2}{*}{$\begin{array}{l}\text { Gerenciais } \\
\text { Técnicas }\end{array}$} & \multirow{2}{*}{ Brandão (2009) } & $\begin{array}{l}\text { Relacionadas ao trabalho dos profissionais } \\
\text { que atuam com atividades de } \\
\text { gestão/coordenação de equipe. }\end{array}$ \\
\hline & & & $\begin{array}{l}\text { Relacionadas ao trabalho específico dos } \\
\text { cargos finalísticos ou administrativos das } \\
\text { organizações. }\end{array}$ \\
\hline
\end{tabular}

Fonte: Elaboração própria, a partir das referências.

Em relação aos diferentes níveis, Brandão (2009) afirma que competências individuais podem determinar as organizacionais, bem como as individuais são influenciadas pelas organizacionais. Essa visão remete a necessidade de alinhamento entre os níveis, de modo que as competências individuais só viabilizarão o bom desenho se estiverem alinhadas às organizacionais para o cumprimento dos objetivos 
estratégicos. Cabe destacar que toda competência coletiva é respectiva de uma equipe e possui uma natureza divergente do que simples soma das competências individuais (SANTOS, 2012). Compreende-se por um modelo de competências válido aquele que aspira estruturar as competências organizacionais e possui uma clara descrição sobre a hierarquização entre competências e subcompetências específicas para cada um dos diferentes indivíduos inseridos em um mesmo contexto de gestão (LIMA; SILVEIRA; TORRES, 2015).

\subsection{Gestão por Competências}

Brito, Carlos e Avelino (2007) definiram gestão por competências como o desenvolvimento de uma arquitetura estratégica e definição de metas de competências prioritárias a serem adquiridas para o desenvolvimento organizacional, a partir da identificação das competências essenciais com o envolvimento das unidades estratégicas da organização. Por conseguinte, embasa-se em um modelo orientado para a geração de resultados sustentáveis, a partir do desenvolvimento das competências dos indivíduos e das equipes alinhadas aos objetivos da organização (CARBONE; TONET; BRUNO; SILVA, 2016).

A gestão por competências consiste em guiar os esforços para planejar, captar, desenvolver e avaliar, nos diferentes níveis da organização: individual, grupal e organizacional, as competências necessárias à consecução de seus objetivos. A captação diz respeito à seleção de competências e à sua integração ao ambiente organiza- cional, que pode dar-se no nível individual, por intermédio de ações de recrutamento e seleção de pessoas e, no nível organizacional, por meio de parcerias ou alianças estratégicas. $\mathrm{O}$ desenvolvimento, por sua vez, refere-se à aprendizagem das competências internas disponíveis na organização que ocorre no nível individual e, no nível organizacional, por intermédio de investimentos em pesquisa. Além da capacitação, a gestão por competências pode utilizar-se de outras estratégias para sanar lacunas de competências, como por exemplo: novas admissões, concursos, remanejamento de pessoal, plano de cargos e salários, e avaliação de desempenho (BRANDÃO; GUIMARÃES, 2001).

Brandão e Bahry (2005) propuseram um modelo de gestão por competências, associando aos subsistemas de gestão de pessoas em que se pode perceber que a definição das competências necessárias (diagnóstico de com- petências) precisa ser feita com base na estratégia organizacional, sendo essenciais para subsidiar os processos de seleção de pessoas (captação de competências), de treinamento e desenvolvimento de pessoal (desenvolvimento de competências), avaliação de desempenho (acompanhamento e avaliação) e remuneração/recompensa por competência (retribuição). Campion et al. (2019) acrescentam que o modelo de competências permite a gestão de talentos da organização, inclusive para situação de gerenciamento da sucessão atrelada ao desempenho.

Os modelos de gestão por competências reforçam que a identificação das competências necessárias deve ser feita a partir de informações da visão estratégica da organização (BRANDÃO; BAHRY, 2005; CAMPION et al., 2011; CHOUHAN; SRIVASTAVA, 2014; AVELINO, NUNES; SARSUR, 2016; CAMPION et al., 2019).

Montezano, Abbad e Freitas (2016), além do alinhamento ao planejamento estratégico, definiram as competências com base na modelagem organizacional provenientes da estrutura organizacionais e dos processos de trabalho. E ainda, tem-se que a definição das competências deve levar em consideração a cultura organizacional, e ainda permite gerar mudanças e melhorias na cultura e no clima organizacional (CAMPION et al., 2019).

\subsection{Gestão por competências na administração pública}

A Gestão por competência pode ser considerada como uma inovação na gestão do setor público, pois propicia a relação da gestão de pessoas com alcance de resultados e o desempenho nas organizações (GUIMARÃES, 2000). A definição das competências é essencial para desenvolver ações de aprendizagem alinhadas às necessida- des da organização, de modo a permitir que os profissionais sejam preparados adequadamente ao trabalho para melhoria da prestação do serviço público (GAETA et al., 2017; ASAME; WAKRIM, 2018).

Apesar de Capuano (2015) afirmar não ser possível desenvolver um modelo universal de gestão por competências para o setor público, indica que o mesmo deve ser concebido com base em processos experimentais, por meio de tentativas e erros. Esta limitação de modelo único de competências também é 
tratada por Getha-Taylor, Blackmar e Borry (2016) ao afirmarem que as competências dependem do contexto, e que precisam ser definidas considerando as necessidades futuras da gestão pública.

Dutra, Hipólito e Silva (2000), em sua pesquisa empírica com gestores do setor de telecomunicações, identificaram como objetivos da gestão por competências: $(i)$ proporcionar percepção de justiça e coerência na gestão de pessoas, ( $i i)$ subsidiar a orientação dos funcionários quanto ao desenvolvimento na organização e maior eficiência na gestão do quadro; (iii) incentivar a capacitação continuada dos funcionários; (iv) definir critérios para diferenciações salariais; e $(v)$ integrar as diferentes práticas de gestão de pessoas, alinhadas ao conceito de competências e que permita a assimilação das mudanças organizacionais e ambientais. Para alcançar estes objetivos, os autores propõem um modelo que contempla a identificação das competências e as utilize para vincular com os processos de recrutamento e seleção, de movimentação de pessoal, de remuneração, de desenvolvimento de pessoas, bem como processos sucessórios. Os autores reforçam a necessidade de envolvimento das pessoas na concepção do modelo a ser implantado, além da divulgação para toda organização com vistas a minimizar as resistências a mudança.

As competências precisam ser debatidas e disseminadas em cada área da organização, para que todos os funcionários tenham um entendimento comum sobre cada competência, além de compreenderem como elas serão medidas e analisadas pela organização (MUNCK; GALLELI; BORIM-DE-SOUZA, 2014; LIMA; SILVEIRA; TORRES, 2015; SKORKOVÁ, 2016). Modelos de gestão em que todos os atores envolvidos, direta ou indiretamente, não tem consciência sobre a sua importância e nem conhecimento do que é esperado dele, estará fadado a enfrentar sérias dificuldades de implementação e gestão (LIMA; SILVEIRA; TORRES, 2015).

Silva, Mello e Torres (2013) identificaram iniciativas quanto à aplicação da noção de competências na esfera pública, principalmente no que diz respeito às ações de capacitação de desenvolvimento de pessoal por competências. No entanto, reforçam que se faz necessário a adoção de outras práticas para efetiva implementação dos modelos de gestão por competências, além da superação das barreiras culturais. Lima e Melo (2017) consta- ram que o patrocínio da alta administração é premissa fundamental para uma implantação efetiva e de qualidade da gestão por competências na Administração Pública. Araújo Júnior e Martins (2014), em bibliometria sobre a implantação do Decreto 5707/2006 constatou que a maioria das publicações tratam da identificação e análise de competências necessárias aos gestores das organizações públicas, assim como Montezano, Medeiros, Isidro- Filho e Petry (2019) constaram sobre a maioria das publicações serem sobre diagnóstico de competências.

Sena e Cunha (2015) afirmaram que a implementação da gestão por competências representa um subproduto da reforma gerencial do Poder Judiciário, e que se refere a uma decisão estratégica. Os autores indicam a necessidade de começar a implantação da gestão por competências na etapa da seleção, aperfeiçoando o concurso público no Tribunal Eleitoral estudado que ainda é feito com avaliação de conhecimentos e não de competências. Ressalta ainda a rigidez que limita a vinculação de práticas de remuneração por competência.

Pestana, Sauerbronn e Morais (2011) indicam que os problemas ficam evidentes quando a máquina pública possui barreiras para a implentação real, o servidor saberia quais normas e regras seguir e as utilizaria de forma correta, além de ter suas competências alinhadas ao alcance dos objetivos organizacionais, o que permitiria o alcance das metas estabelecidas e a redução de gastos públicos. Os autores indicam que a insuficiência de recursos financeiros das organizações também compromete o desenvolvimento das competências. O Quadro 2 sintetiza as principais dificuldades identificadas em estudos sobre a implantação da gestão por competências.

Quadro 2 - Principais dificuldades sobre implantação da gestão por competências da literatura

\begin{tabular}{|c|l|}
\hline Referência & \multicolumn{1}{c|}{ Barreiras / Dificuldades } \\
\hline $\begin{array}{c}\text { Munck, Munck e Borim-de- } \\
\text { Souza (2011) }\end{array}$ & Divergências sobre o modelo na empresa e da cultura organizacional. \\
\hline Silva et al. (2013) & $\begin{array}{l}\text { Dificuldades a aprender a nova forma de trabalhar, resistências do indivíduo, clima e } \\
\text { cultura organizacional. }\end{array}$ \\
\hline $\begin{array}{c}\text { Fevorini, Silva e Crepaldi } \\
(2014)\end{array}$ & A inserção do conceito de competências a todos. \\
\hline
\end{tabular}




\begin{tabular}{|c|c|}
\hline $\begin{array}{l}\text { Munck, Galleli e Souza } \\
\text { (2014) }\end{array}$ & Divergências do conceito que rege o modelo na empresa e da cultura organizacional. \\
\hline Lucas (2015) & Implantação na visão de servidores acomodados, cultura organizacional pública do país. \\
\hline $\begin{array}{l}\text { Magalhães, Dalmau eGaubert } \\
\text { (2015) }\end{array}$ & $\begin{array}{l}\text { Falta de apoio da alta administração, resistência dos servidores, excesso de trabalho e } \\
\text { desmotivação da equipe de mapeamento de competências. }\end{array}$ \\
\hline $\begin{array}{l}\text { Henklain, Teixeira, Bastos e } \\
\text { Lukianou (2016) }\end{array}$ & $\begin{array}{l}\text { Desconhecimento dos gestores e profissionais quanto aos reais princípios do modelo de } \\
\text { gestão, inerentes a resistências a mudança }\end{array}$ \\
\hline Landfeldt eOdelius (2017) & $\begin{array}{l}\text { A falta de acessibilidade às unidades; apoio dos gestores, servidores e da alta gestão; falta } \\
\text { de recursos financeiros, materiais, de pessoal e de sistemas informatizados; a falta de } \\
\text { orientação do governo federal; desconhecimento da política e de sua importância; } \\
\text { descontinuidade da gestão e/ou saída de profissionais da equipe responsável pela GC; } \\
\text { sobrecarga de atribuições e limitações legais para implantação do modelo. }\end{array}$ \\
\hline Côrtes e Meneses (2019) & $\begin{array}{l}\text { Identificaram quatro categorias com } 21 \text { aspectos dificultadores: institucional (ex: } \\
\text { legislação e normas externas); político (ex: apoio da alta administração); organizacional } \\
\text { (cultura organizacional), e setorial (ex: metodologia de implementação). }\end{array}$ \\
\hline $\begin{array}{l}\text { Montezano, Medeiros, } \\
\text { Pinheiro e Oliveira (2019) }\end{array}$ & $\begin{array}{l}\text { Cultura organizacional da Administração Pública, limitações metodológicas e práticas da } \\
\text { gestão por competências, falta de apoio da alta administração, restrições orçamentárias e } \\
\text { de pessoal para implantação, falta de engajamento dos servidores, restrições no processo } \\
\text { de comunicação do modelo de gestão por competências. }\end{array}$ \\
\hline $\begin{array}{l}\text { Montezano, Med eiros , Isidr } \\
\text { Filho e Petry (2019) }\end{array}$ & $\begin{array}{l}\text { Consolidaram } 45 \text { dificuldades em seis categorias: comportamento organizacional (ex: } \\
\text { cultura organizacional); dificuldades dos gestores e equipe de implantação (ex: falta de } \\
\text { equipe específica qualificada para implantação); particularidades do contexto da gestão } \\
\text { pública (ex: aspectos legais e normativos); dificuldades metodológicas e conceituais da } \\
\text { gestão por competências (ex: complexidade na elaboração das descrições de } \\
\text { competências); falta de suporte organizacional (ex: falta de apoio da alta administração); e } \\
\text { características da organização (ex: tamanho da organização). }\end{array}$ \\
\hline
\end{tabular}

Fonte: Pesquisa realizada pelas autoras.

A implementação de um modelo uniformizado para a Justiça Eleitoral, no que diz respeito às competências, apresentam ganhos para a dinâmica organizacional, porém só se concretizarão ao atingir os objetivos como: apontar os aspectos a serem aprimorados na gestão; objetivar a avaliação de pessoas; estabelecer critérios para o autodesenvolvimento; oferecer aos gestores oportunidade de receber feedback qualificado; facilitar a oferta de feedback e contribuir para a melhoria na gestão (BRASIL, 2013). Essa orientação de competências pode ser usada como vantagem, pois incentiva o servidor a se esforçar para realizar seu ofício de forma eficiente, como também atingir um grau de qualidade e de excelência nas funções referentes aos cidadãos (SANTOS, 2012). O Quadro 3 apresenta a relação de benefícios apontados por autores sobre a implantação da gestão por competências.

Quadro 3 - Principais benefícios sobre implantação da gestão por competências na literatura

\begin{tabular}{|c|l|}
\hline Referência & \multicolumn{1}{|c|}{ Benefícios } \\
\hline Silva et al.,2013 & $\begin{array}{l}\text { Auxílio no desenvolvimento do conhecimento, das habilidades e atitudes dos } \\
\text { profissionais. }\end{array}$ \\
\hline $\begin{array}{c}\text { Fevorini,Silva e } \\
\text { Crepaldi(2014) }\end{array}$ & A importância da gestão de pessoas com a estratégia organizacional \\
\hline Munk, Galleli e Souza (2014) & Sustenta o modelo de competências em prol de que uma segunda prova seja alcançada. \\
\hline Lucas (2015) & As capacidades de mapear as competências. \\
\hline Capuano (2015) & $\begin{array}{l}\text { Oferece parâmetros mais técnicos e realistas para o planejamento da força de trabalho, } \\
\text { recrutamento e seleção, remuneração, avaliação e retribuição por desempenho, } \\
\text { promoção. }\end{array}$ \\
\hline $\begin{array}{c}\text { Henklain, Teixeira, Bastos e } \\
\text { Lukianou (2016) }\end{array}$ & $\begin{array}{l}\text { Diminuição de rotatividade e absenteísmo, aumento da satisfação dos clientes, maior } \\
\text { alinhamento entre os subsistemas de gestão de pessoas e a estratégia organizacional, } \\
\text { clareza quanto à aspectos de carreira, maior valorização do profissional. }\end{array}$ \\
\hline
\end{tabular}




\begin{tabular}{|c|l|}
\hline Skorková (2016) & $\begin{array}{l}\text { Permite clareza do que se espera do profissional, suporte à gestão da carreira do } \\
\text { servidor, contribui com processos de gestão de pessoas (contratação, movimentação, } \\
\text { avaliação de desempenho e treinamento), bem como com a integração entre eles. }\end{array}$ \\
\hline Gaeta et al. (2017) & $\begin{array}{l}\text { Identificar o perfil necessário para alocação nas áreas, de modo a evitar que falte } \\
\text { profissionais com as competências adequadas; desenvolver as competências dos } \\
\text { servidores, considerando as restrições da organização; minimizar a insatisfação dos } \\
\text { profissionais. }\end{array}$ \\
\hline Landfeldt eOdelius (2017) & $\begin{array}{l}\text { Melhoria e maior integração na gestão de pessoas; maior objetividade nos processos de } \\
\text { avaliação; melhoria no dimensionamento de pessoal; melhorias realizadas no Plano } \\
\text { anual de capacitação (PAC) e consciência e valorização das necessidades de capacitação; } \\
\text { alteração na cultura organizacional; alteração na forma de pensar dos servidores; } \\
\text { identificam a mudança como positiva não só para a organização, mas também para a } \\
\text { sociedade e para eles. }\end{array}$ \\
\hline Montezano, Medeiros, \\
Pinheiro e Oliveira (2019) & $\begin{array}{l}\text { Melhorias no desempenho individual e organizacional, melhoria na alocação de pessoal, } \\
\text { desenvolvimento de pessoal, maior envolvimento como trabalho, melhoria no clima } \\
\text { organizacional, alinhamento estratégico, gestão de carreira do servidor. }\end{array}$ \\
\hline
\end{tabular}

Fonte: Pesquisa realizada pelas autoras

\section{Método}

Devido a finalidade de descrever o processo de implantação na Justiça Eleitoral como um todo, esta pesquisa é teórico-empírica, de natureza descritiva e com recorte temporal transversal. Mediante abordagem metodológica quantitativa e qualitativa, utilizou-se técnicas de coletar dados de pesquisa documental, entrevistas e questionários.

Foram analisados normativos, planejamento estratégico e relatórios publicados sobre a gestão por com- petências na Justiça Eleitoral. As entrevistas ocorreram com gestores de dois Tribunais Eleitorais (um Superior e outro Regional), que atuam na área de gestão de pessoas e gestão estratégica, com intuito de compreender o pro- cesso de implementação na Justiça Eleitoral. O público destinado a responder o questionário foram profissionais que estivessem atuando na implantação da gestão por competências, e em caso de não haver adotado o modelo que fossem respondidos pelos responsáveis pelas unidades de gestão de pessoas dos Tribunais, totalizando em uma população de 28 Tribunais.

O questionário foi elaborado a partir da análise da literatura, da pesquisa documental e das entrevistas realizadas, e validado semanticamente com os gestores que participaram das entrevistas. A versão final do ins- trumento de pesquisa foi estruturada em quatro partes: ( $i$ ) adoção do modelo de gestão por competências - GC, com dois itens de múltipla escolha; (ii) compreensão do modelo de gestão por competência com 10 questões, a ser respondida somente pelos Tribunais que possuem iniciativas quanto à adoção de modelo de CG; (iii) dificuldades e vantagens dos modelos de gestão por competências (perguntas abertas), e (iv) características socioprofissio- nais com sete questões. Os dados foram obtidos por meio da aplicação eletrônica do instrumento, em link do Google forms, disponibilizado por e-mail e pelos formulários de solicitação de informação dos sites institucionais (Ouvidorias). Com isso, a amostragem utilizada foi a não probabilística por conveniência, devido ao critério da participação voluntária.

A técnica de análise de dados quantitativos empregada foi a estatística descritiva, por meio da frequência das respostas das perguntas fechadas e a dos dados qualitativos foi análise de conteúdo, com a participação de três especialistas em gestão de pessoas, sendo todos mestres e dois doutorandos em Administração. Após as respostas dos especialistas, o que permitiu a triangulação dos dados sob ótica de diferentes indivíduos, os dados foram consolidados pelas pesquisadoras responsáveis, de acordo com os critérios de homogeneidade, exclusão e pertinência propostos por Bardin (2016). Com isso, foi possível definir categorias de conteúdo para cada uma das respostas, com sua definição constitutiva, exemplo e contagem dos relatos que foram relacionados a cada uma das categorias

$\mathrm{Na}$ apresentação dos resultados, com intuito de assegurar o sigilo dos respondentes, instituiu-se códigos que são usados para exemplificar relatos da pesquisa, sendo QTn para Questionário do Tribunal, 
onde " $n$ " é a numeração na ordem que foram respondidos, e os códigos EG1 e EG2 para Entrevista com Gestor 1 e 2.

\section{Resultados e Discussão}

\subsection{Status da implantação}

Obteve-se participação de 22 Tribunais, o que pode ser considerada uma amostra representativa por contemplar 78,5\% da população estudada, sendo três da região Sul; quatro da Sudeste; quatro da CentroOeste (um Tribunal Superior e três Regionais); cinco do Norte; e seis da Nordeste.

O perfil dos respondentes pode ser caracterizado principalmente como: 12 pessoas do sexo feminino, 10 tem idade entre 41 e 50 anos e oito entre 31 a 40 anos, 15 respondentes possuem especialização/ MBA e seis com mestrado. Quanto ao perfil profissional, 13 participantes foram gestores responsáveis pela implementação da gestão por competências e nove servidores que atuam na área. A distribuição do tempo de serviço no Tribunal mostrou-se equilibrada em três intervalos de período, sendo seis pessoas com 5 a 10 anos, seis entre 10 a 15 anos e cinco com 20 a 25 anos. Já o tempo em que os profissionais trabalham com gestão por competências foram sete entre 1 a 3 anos, seis entre 3 a 5 anos, quatro entre 7 e 10 anos, três entre 5 a 7 anos e dois com menos de 1 ano. E ainda, em todos os Tribunais os respondentes indicaram ter conhecimento de algum modelo de gestão de pessoas por competências.

Dos participantes da pesquisa, 16 Tribunais declaram que adotam algum modelo de gestão por competências enquanto seis ainda não o fazem, mas indicaram estarem realizando estudos sobre o tema com vistas à realização de iniciativas relacionadas ao desenvolvimento do modelo. Este aspecto já demonstra que houve uma evolução no quantitativo dos Tribunais que iniciaram atividades relacionadas à implementação deste modelo, em relação ao relatório publicado em 2013 em que haviam apenas 11 Tribunais (BRASIL, 2013). Cabe destacar que dos 16 participantes, 15 respondentes informaram ter participação na concepção do modelo de gestão por competência no seu respectivo Tribunal e apenas uma pessoa teve participação parcial, o que indica que foram pessoas com conhecimentos suficientes para contribuir com a pesquisa.

O primeiro Tribunal a iniciar a implantação do modelo da gestão por competências na Justiça Eleitoral foi o TSE em 2005, levando em consideração os benefícios que estas práticas poderiam trazer para melhorias da gestão do Órgão, mesmo antes do Decreto 5707/2006. Depois desta iniciativa, dois Tribunais iniciaram a adoção em 2008, e os anos com maior índice de implantação foram os de 2013 e 2015, conforme ilustrado na Figura 1.

Figura 1 - Quantitativo da evolução da implantação da gestão por competências em Tribunais da Justiça Eleitoral

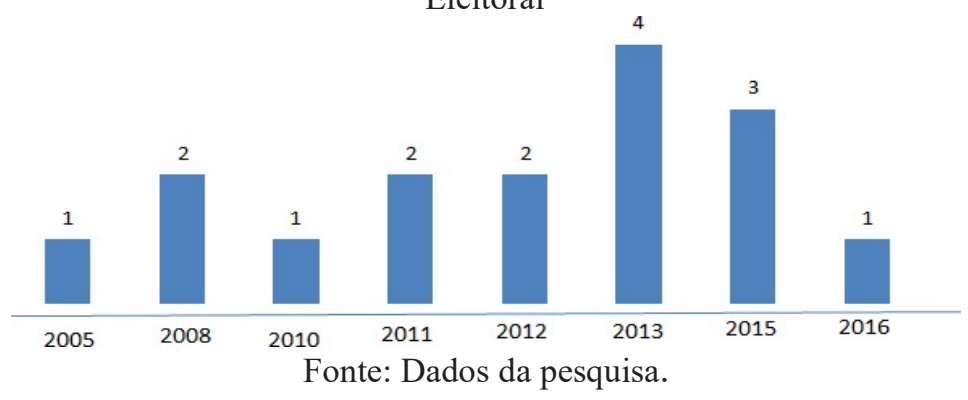

Dentre os Tribunais que indicaram adotar algum modelo de gestão por competências, os principais motivos elencados foram quanto ao cumprimento de recomendações de órgãos de controle por seis respondentes, e a própria necessidade definida pela organização, em função do conhecimento acerca dos benefícios do modelo, no caso de cinco Tribunais. Além disso, dois indicaram que foi em decorrência de exigência normativa do próprio Tribunal, um em função do Decreto 5707/2006, um em função de se inspirarem em outras organizações que adotam o modelo, e um por outros motivos não especificados.

Pode-se perceber que há um alinhamento entre os motivos que estão levando a utilização do modelo de gestão por competências com o que foi apontado por outros estudos quanto à preocupação com a busca 
da melhoria dos resultados nas organizações públicas (GUIMARÃES, 2000; BRASIL, 2009; SKORKOVÁ, 2016), pois a Justiça Eleitoral iniciou sua implantação pelo Tribunal Superior Eleitoral, mesmo antes da normatização para a esfera federal, por acreditar nos resultados oferecidos por esta abordagem de gestão, conforme indicado em entrevista. Entende-se que a própria publicação do Decreto 5707/2006, os normativos dos Tribunais e as recomendações dos órgãos de controle sejam em função da busca pela melhoria na prestação do serviço da administração pública.

Todos os Tribunais indicaram a utilização de mais de uma fonte de pesquisa de informações para concepção dos respectivos modelos, sendo que 14 consultaram modelos publicados em livros e experiências em outros Tribunais da Justiça Eleitoral, 13 fizeram cursos específicos sobre gestão por competências para adquirir conhecimentos necessários ao desenvolvimento dos modelos, 11 buscaram normativos de outros órgãos sobre o tema, nove pesquisaram modelos de produções científicas (artigos), sete fizeram pesquisas em outros órgãos públicos e três em organizações não públicas (ex: privadas, economia mista). Observa-se que as equipes respon- sáveis pela implantação do modelo de gestão por competências dos Tribunais da Justiça Eleitoral têm buscado referências em estudos publicados, procurado se capacitar para atendimento da demanda com profissionais mais qualificados, bem como realizado benchmarking de boas práticas para o desenvolvimento de modelos adequados, inclusive entre os próprios Tribunais para adequação à realidade organizacional. Este aspecto está alinhado com o que Capuano (2015) indicou quanto a busca por experiências de outros órgãos, de modo a conhecer as dificulda- des, os modelos e poder conceber seus próprios modelos específicos.

Para a definição das competências, 13 Tribunais utilizam mais de uma fonte de informação organizacio- nal, enquanto três utilizam apenas uma fonte, sendo que dois Tribunais usam somente processos de trabalho e um usa normativos das atribuições das áreas. Dos que adotam mais de uma fonte, oito são provenientes de três fontes distintas, sendo elas: o planejamento estratégico, os processos de trabalho e as atribuições das áreas ou dos cargos. Dentre as opções indicadas no questionário, as informações utilizadas para a definição de competências, 14 Tribunais utilizam os processos de trabalho, 10 se orientam pelo Planejamento Estratégico, oito analisam os normativos com as atribuições das áreas, e sete os normativos com as atribuições dos cargos. Além disso, dois tribunais indicaram outras fontes de informações para a definição das competências sendo um por meio de reuniões com gestores das áreas e o outro com as equipes de trabalho.

Quanto às fontes utilizadas para concepção dos modelos de gestão por competências, os Tribunais têm adotado as recomendações propostas pela literatura, indicando que realmente as pesquisas para conceber o modelo estão sendo colocadas em prática, uma vez que as fontes de informação organizacional tem sido os processos de trabalho, conforme foi realizado por Montezano, Abbad e Freitas (2016) e o planejamento estratégico conforme diversos autores recomendam (BRANDÃO; BAHRY, 2005; CHOUHAN; SRIVASTAVA, 2014; AVELINO, NUNES; SARSUR, 2016; CAMPION et al., 2019).

Pode-se perceber essencialmente que a técnica de coleta de dados mais utilizada é a pesquisa documental, tendo dois Tribunais que buscam outras fontes de coletas como as entrevistas individuais e coletivas com os gestores e esquipes, alinhado ao que é recomendado por Brandão e Bahry (2005).

A partir da análise destas informações, os Tribunais puderam definir suas competências, como etapa inicial da implementação do modelo. Quanto aos níveis das competências adotados pela Justiça Eleitoral, constatou-se que nove Tribunais possuem identificadas as competências organizacionais, de equipe e individual; três possuem dois níveis (organizacional e individual), e três possuem apenas um nível, sendo dois no nível de equipes e um somente no organizacional. Um dos Tribunais indicou não adotar este tipo de classificação para a definiç̧ão de suas competências, e não indicou a existência de alguma classificação pelo Órgão. Percebe-se que há uma busca pela concepção de modelos mais abrangentes com a especificação de diferentes níveis para gerar melhores resultados, conforme apontado por Brandão (2009).

Apenas metade dos Tribunais (8) indicaram terem observado o alinhamento entre as competências individuais e organizacionais durante sua identificação, um Tribunal indicou que não há alinhamento, mesmo tendo especificado a identificação nos três níveis. Os demais Tribunais indicaram que a pergunta não se aplicava ao contexto da sua organização, mesmo apesar de três deles terem indicado a definição das competências nos níveis organizacional e individual, indicando também que não houve preocupação em alinhamento no momento de suas definições. Isso é um ponto preocupante, pois sem o alinhamento na 
definição das competências nos diferentes níveis, não há direcionamento e articulação entre as competências para gerar os resultados necessários, conforme indicado por Brandão (2009), comprometendo assim a validade do modelo de competências (LIMA; SILVEIRA; TORRES, 2015).

Ainda sobre a classificação das competências, quanto à amplitude, 13 Tribunais indicaram possuir as gerais ou transversais e 15 as específicas, sendo que 12 Tribunais adotam os dois tipos, 3 somente as específicas e uma somente as transversais. Quanto à especificidade, 14 Tribunais indicaram o estabelecimento de competên- cias gerenciais e 16 de técnicas.

Em relação à temporalidade, há predomínio na utilização de competências estáveis em 15 Tribunais, sendo que deles cinco também adotam as competências emergentes, e 1 não adota este tipo de classificação. Observa- se que houve divergência com os dados coletados no que diz respeito ao fato de apenas cinco Tribunais estabelecerem competências com foco em demandas no futuro, sendo que 10 haviam indicado utilizar o Planejamento Estratégico como fonte para definição das competências, sendo que esta deveria subsidiar a visão das necessida- des futuras da organização.

Dentre a utilização das competências nos subsistemas de gestão de pessoas, 15 Tribunais subsidiam os processos de Treinamento e Desenvolvimento, nove os de Avaliação de Desempenho, oito os de Movimentação interna de pessoal, três estão utilizando para realização de concurso público e um para remuneração. A principal recorrência estar relacionada aos processos de capacitação, possivelmente deve ser em função da busca pelo cumprimento do Decreto 5707/2006, corroborando ao que foi apontado por Silva, Mello e Torres (2013), inclusive quanto ao fato da necessidade de adoção das outras práticas para efetiva implantação do modelo. A limitação do uso das competências para as etapas de recrutamento e seleção e remuneração estão alinhadas aos resultados do estudo de Sena e Cunha (2015).

A partir da análise da literatura, foram elencadas nove etapas do modelo de gestão por competências para verificar quais delas foram contempladas no processo de implantação deste modelo nos Tribunais, as quais são apresentadas no Quadro 4 com as respectivas frequências absolutas $\left(f_{a}\right)$.

Quadro 4 - Etapas que são realizadas no modelo de gestão pelos Tribunais Eleitorais

\begin{tabular}{|l|c|}
\hline Etapas & $\left(\mathbf{f}_{\mathbf{a}}\right)$ \\
\hline Identificação de lacunas de competências profissionais & 15 \\
\hline Execução de ações de aprendizagem com base nas lacunas de competências & 15 \\
\hline Identificação de competências profissionais & 15 \\
\hline Elaboração do plano de capacitação por competências & 14 \\
\hline Identificação de competências organizacionais & 12 \\
\hline Disseminação das competências para os profissionais & 9 \\
\hline Análise do contexto organizacional & 8 \\
\hline Avaliação de desempenho com base em competências profissionais & 7 \\
\hline $\begin{array}{l}\text { Resultados da avaliação de desempenho por competências para retroalimentar as } \\
\text { necessidades de capacitação }\end{array}$ & 7 \\
\hline
\end{tabular}

Fonte: Pesquisa de Campo

Pode-se observar que em 15 Tribunais as etapas mais recorrentes são identificação de competências profissionais e de suas lacunas que subsidiam a execução de ações de aprendizagem. Nem todos os Tribunais elaboram plano de capacitação com base em competências, sendo que inclusive um deles que não identifica competências profissionais, elabora o plano sem levantar as lacunas existentes, e o faz com base nas competências organizacionais. Observa-se alinhamento deste resultado com os estudos de Araújo Júnior e Martins (2014) quanto à etapa de identificação de competências e Montezano, Medeiros e IsidroFilho e Petry (2019) quanto à etapa de diagnóstico de competências ser a mais investigada do modelo de gestão por competências na adminis- tração pública. As organizações precisam avançar na implantação de outras etapas da gestão por competências, conforme apontado por Silva, Mello e Torres (2013).

Tem-se no Quadro 4, também, que nove Tribunais disseminam as competências aos profissionais que trabalham na Organização. Apesar de ser mais da metade dos participantes da pesquisa, este ponto precisa 
de aperfeiçoamento, pois é um fator chave para o sucesso da implantação do modelo de gestão por competências (MUNCK; GALLELI; SOUZA, 2014; LIMA; SILVEIRA; TORRES, 2015). Outros pontos que ainda precisam ser aperfeiçoados nos Tribunais é o fato da necessidade de utilizarem a análise do contexto organizacional para a definição das competências, bem como utilizar os resultados da avaliação de desempenho para retroalimentar outros subsistemas de gestão de pessoas, conforme recomendado no modelo de Brandão e Bahry (2005).

Dos Tribunais que adotaram o modelo, 13 indicaram grau de concordância quanto a terem recebido apoio da alta administração para o desenvolvimento e implantação da gestão por competências, o que é considerado um ponto positivo para o sucesso da adoção, conforme apontado por Lima e Melo (2017). No entanto, três Tribunais indicaram que não houve nenhum apoio da alta administração.

Para a adoção da gestão por competências, 13 Tribunais indicaram grau de concordância com o fato de terem enfrentado barreiras/dificuldades, e três indicaram alto grau de discordância neste aspecto. A maioria dos respondentes (11) possui percepção de terem ocorridos benefícios para o Tribunal com o que já foi adotado da gestão por competências, enquanto que cinco tiveram grau de discordância quanto aos efeitos dos benefícios do modelo. Além disso, nove participantes indicaram grau de concordância em haver melhorias na atuação dos servidores em função da implantação da gestão por competências, sendo que dois deles tiveram concordância total, e sete tiveram graus de discordância em terem ocorrido melhorias, sendo que três apontaram não terem tido nenhuma percepção quanto a isso. A seguir, são detalhados os benefícios e dificuldades relacionados à adoção do modelo de gestão por competências na Justiça Eleitoral.

\subsection{Beneficios da implantação da gestão por competências}

Foi questionada a percepção quanto aos benefícios da adoção da gestão por competências na Justiça Eleitoral, independentemente de terem implementado ou não no respectivo Tribunal. Neste caso, foram elencados 74 relatos, o que remete que mesmo com todas as dificuldades, incluindo os desafios conceituais e metodológicos, os participantes da pesquisa possuem ciência dos benefícios em utilizar modelos de gestão por competência. A consolidação dos dados gerou a definição de nove categorias, as quais são apresentadas no Quadro 5, com suas respectivas descrições, exemplos e quantitativo dos relatos de cada uma delas. A definição final das categorias foi feita com base na análise dos dados e na análise da literatura.

Quadro 5 - Benefícios possíveis com a adoção do modelo de gestão por competências para Justiça Eleitoral

\begin{tabular}{|c|c|c|c|}
\hline Categorias & Descrição & Exemplos de relatos & $\begin{array}{l}\text { Qtd. de } \\
\text { relatos }\end{array}$ \\
\hline $\begin{array}{l}\text { Alinhamento } \\
\text { Estratégico }\end{array}$ & $\begin{array}{l}\text { Refere-se à possibilidade de alinhamento } \\
\text { das competências definidas com a } \\
\text { estratégia organizacional para direcionar } \\
\text { os esforços ao alcance dos resultados } \\
\text { almejados. }\end{array}$ & $\begin{array}{l}\text { "Competências alinhadas à consecução } \\
\text { dos objetivos institucionais" (QT5). }\end{array}$ & 5 \\
\hline $\begin{array}{c}\text { Políticas e Práticas } \\
\text { de Gestão de } \\
\text { Pessoas }\end{array}$ & $\begin{array}{l}\text { Refere-se à possibilidade do alinhamento } \\
\text { dos subsistemas de gestão de pessoas com } \\
\text { adoção de políticas e práticas usando as } \\
\text { competências. }\end{array}$ & $\begin{array}{l}\text { "Um modelo de gestão de pessoas } \\
\text { metodologicamente consistente, que } \\
\text { apoiasse e integrasse as práticas de } \\
\text { seleção, capacitação, lotaçãor e } \\
\text { reconhecimento"(QT7). }\end{array}$ & 7 \\
\hline $\begin{array}{c}\text { Gestão de } \\
\text { Desempenho }\end{array}$ & $\begin{array}{l}\text { Refere-se à possibilidade de } \\
\text { direcionamento, manutenção e melhoria } \\
\text { dos esforços no trabalho com uso de } \\
\text { competências para o alcance de resultados } \\
\text { com maior produtividade e qualidade na } \\
\text { prestação do serviço público. }\end{array}$ & $\begin{array}{l}\text { "Uma instituição voltada para o } \\
\text { desempenho por resultado" (QT3). }\end{array}$ & 13 \\
\hline $\begin{array}{c}\text { Organização do } \\
\text { Trabalho }\end{array}$ & $\begin{array}{l}\text { Refere-se à possibilidade de orientar e } \\
\text { direcionar o servidor na realização do } \\
\text { trabalho, com base na clareza das } \\
\text { competências que precisa desempenhar. }\end{array}$ & "Distribuição do trabalho" (QT1). & 3 \\
\hline
\end{tabular}




\begin{tabular}{|c|c|c|c|}
\hline $\begin{array}{c}\text { Educação } \\
\text { Corporativa }\end{array}$ & $\begin{array}{l}\text { Refere-se à possibilidade de desenvolver } \\
\text { os servidores nas competências necessárias } \\
\text { ao desempenho do seu trabalho para o } \\
\text { alcance dos resultados organizacionais } \\
\text { esperados. }\end{array}$ & $\begin{array}{l}\text { "Desenvolvimento de planos de } \\
\text { capacitação voltados a atender às } \\
\text { competências profissionais desejadas } \\
\text { pela Organização" (EG2). }\end{array}$ & 15 \\
\hline $\begin{array}{c}\text { Alocação e } \\
\text { Movimentação de } \\
\text { Pessoas }\end{array}$ & $\begin{array}{l}\text { Refere-se à possibilidade de planejar, } \\
\text { alocar e movimentar servidores de acordo } \\
\text { com o perfil de competências necessárias à } \\
\text { atuação em cada cargo e unidade } \\
\text { organizacional. }\end{array}$ & $\begin{array}{l}\text { "Melhoria no processo de lotação dos } \\
\text { servidores, possibilitando melhor } \\
\text { aproveitamento de suas competências" } \\
\text { (QT4). }\end{array}$ & 14 \\
\hline $\begin{array}{l}\text { Política de } \\
\text { Sucessores }\end{array}$ & $\begin{array}{l}\text { Refere-se à possibilidade da transparência } \\
\text { das competências gerenciais desejadas } \\
\text { para ocupação de funções comissionadas, } \\
\text { permitindo o preparo dos servidores para } \\
\text { continuidade da gestão. }\end{array}$ & $\begin{array}{l}\text { "Facilita a implantação de processos } \\
\text { sucessórios" (QT1). }\end{array}$ & 4 \\
\hline $\begin{array}{l}\text { Políticas de } \\
\text { Valorização e } \\
\text { Satisfação do } \\
\text { Servidor }\end{array}$ & $\begin{array}{l}\text { Refere-se à possibilidade de } \\
\text { reconhecimento institucional do servidor } \\
\text { pela demonstração de suas competências. }\end{array}$ & $\begin{array}{l}\text { "Nesse tipo de gestão as pessoas são } \\
\text { valorizadas, e isso é bom, porque } \\
\text { precisamos incentivar e reconhecer as } \\
\text { boas e melhores práticas de gestão e } \\
\text { também de preparar, cuidar dos talentos } \\
\text { que já existem e incentivar o } \\
\text { aparecimento de novos" (QT3). }\end{array}$ & 8 \\
\hline $\begin{array}{c}\text { Clima } \\
\text { Organizacional }\end{array}$ & $\begin{array}{l}\text { Refere-se à possibilidade de um ambiente } \\
\text { favorável ao relacionamento profissional } \\
\text { para execução do trabalho de maneira } \\
\text { adequada, em função da ciência do que é } \\
\text { esperado de cada um. }\end{array}$ & $\begin{array}{l}\text { "Melhoria no relacionamento entre } \\
\text { gestores e liderados" (QT9). }\end{array}$ & 5 \\
\hline
\end{tabular}

Fonte: Dados da pesquisa.

O principal aspecto apontado como melhoria da implantação do modelo de gestão por competências está relacionado à Educação corporativa, o que pode ser decorrente do próprio Decreto 5.707/2006 que estabelece sobre o desenvolvimento de competência do servidor público, conforme Araújo Júnior e Martins (2014). E ainda, este resultado também está alinhado com o que vem sendo apontado pelos estudos acerca de gestão por competências em função da relevância que o modelo permite o desenvolvimento de competências específicas dos profissionais (SILVA et al.,2013; LANDFELDT; ODELIUS, 2017; MONTEZANO; MEDEIROS; PINHEIRO; OLIVEIRA, 2019).

Em seguida, de acordo com a percepção dos participantes da pesquisa, a possibilidade de realizar movimentações internas e alocações de servidores, de acordo com os perfis de competências necessários à realização do trabalho é outro benefício que a Justiça Eleitoral pode obter com a adoção da gestão por competência, confor- me também foi identificado por Capuano (2015), Landfeldt e Odelius (2017) e Montezano, Medeiros, Pinheiro e Oliveira (2019). A gestão de desempenho também merece destaque pelo fato de permitir a obtenção de melhores resultados individuais e organizacionais, sendo que esta gestão só será possível a partir do alinhamento com a estratégia para direcionar aos resultados esperados (FEVORINI; SILVA; CREPALDI, 2014; MONTEZANO; MEDEIROS; PINHEIRO; OLIVEIRA, 2019) e devido à clareza aos servidores do que é esperado deles, a con- tar do mapeamento de competências (LUCAS, 2015; SKORVOVÁ, 2016). Os achados também corroboram com Campion et al. (2019) no sentido de que a adoção da gestão por competências propiciou melhorias de clima organizacional na Justiça Eleitoral.

De modo geral, os benefícios indicados pelos participantes estão alinhados com a literatura, o que demonstra conhecimento dos servidores acerca das vantagens da implementação da gestão por competências. E ainda, remete a aspectos específicos do contexto estudado, no qual foram indicados aspectos relacionados à política de sucessão, indo além de visões gerais quanto à carreira do servidor público, conforme achados em outras pesquisas, como na de Henklain, et al. (2016) e Campion et al. (2019).

No caso específico dos Tribunais que implementaram alguma ação de Gestão por Competências, foram obtidos 31 relatos relativos aos ganhos obtidos com a adoção do modelo. A análise dos dados gerou as cinco categorias de conteúdo, as quais são apresentadas em ordem decrescente do quantitativo de relatos: desenvolvimento de pessoal (14); mapeamento de competências (8); melhorias no desempenho (5); 
melhorias na alocação de servidores (3); e desenvolvimento de políticas de sucessores (1).

Pode-se perceber que houve alinhamento entre quatro categorias dos benefícios já obtidos com os que são esperados a partir da adoção de modelos de gestão por competências nas organizações, sendo acrescentado o ganho quanto ao mapeamento de competências que foi relatado pela metade dos Tribunais como sendo uma etapa essencial em que permite identificar as competências profissionais necessárias, as quais subsidiarão os demais subsistemas de gestão de pessoas por competências, assim como permite ao servidor ter ciência do que é esperado dele no seu trabalho, conforme apontado por Lucas (2015), Gaeta et al. (2017) e Asame e Wakrim (2018). Observa-se que cinco categorias que consideram como possibilidade de benefícios com a gestão por competên- cias (alinhamento estratégico; políticas de gestão de pessoas; organização de trabalho; políticas de valorização e satisfação; e relações interpessoais e clima) ainda não foram percebidas como algo que foi obtido nos Tribunais que participaram da pesquisa, o que remete a necessidade de superação das dificuldades para que possam ser alcançados. Sendo assim, a seguir são apresentadas as dificuldades e sugestões de melhorias para a implantação da gestão por competências, a partir dos dados coletados.

\subsection{Dificuldades e melhorias da implantação da gestão por competências}

Dentre todos os Tribunais que participaram da pesquisa, foram levantados 51 relatos acerca das dificuldades para adoção da gestão por competências em seus Órgãos. Ao consolidar as categorias de conteúdo, a partir da análise de juízes, percebeu-se alinhamento da proposição feita por eles, tendo como resultado final seis categorias, as quais são apresentadas no Quadro 6, com suas respectivas definições constitutivas, elaboradas com base nos relatos dos participantes e da literatura da área. O Quadro 6 contém exemplos dos relatos que subsidiaram a criação da categoria, bem como sua quantidade.

Quadro 6 - Dificuldades identificadas para implantação do modelo de gestão por competência na Justiça Eleitoral

\begin{tabular}{|c|c|c|c|}
\hline Categorias & Definição constitutiva & Exemplo de Relatos & $\begin{array}{l}\text { Qtd. de } \\
\text { relatos }\end{array}$ \\
\hline $\begin{array}{l}\text { Aspectos } \\
\text { culturais do } \\
\text { serviço público }\end{array}$ & $\begin{array}{l}\text { Refere-se aos aspectos relacionados aos } \\
\text { comportamentos das pessoas nas organizações } \\
\text { públicas, bem como as práticas gerais adotadas } \\
\text { na gestão, incluindo aspectos normativos. }\end{array}$ & $\begin{array}{l}\text { “A Administração Pública, na } \\
\text { prática, não prioriza as } \\
\text { competências para a tomada de } \\
\text { decisões" (QT20). }\end{array}$ & 7 \\
\hline $\begin{array}{l}\text { Desafios } \\
\text { estruturais do } \\
\text { Tribunal }\end{array}$ & $\begin{array}{l}\text { Refere-se aos aspectos contextuais de estrutura } \\
\text { da organização relacionados à hierarquia, } \\
\text { comunicação, disponibilidade orçamentária e } \\
\text { da força de trabalho, incluindo sua } \\
\text { qualificação, bem como a existência de equipes } \\
\text { específicas para atuar com demandas de gestão } \\
\text { por competências. }\end{array}$ & “Questões orçamentárias” (EG2). & 9 \\
\hline $\begin{array}{c}\text { Falta de } \\
\text { suporte da Alta } \\
\text { administração e } \\
\text { dos gestores }\end{array}$ & $\begin{array}{l}\text { Refere-se à carência de apoio e patrocínio da } \\
\text { alta administração relacionada à priorização de } \\
\text { demandas para implementação da gestão por } \\
\text { competências, bem como da ausência de } \\
\text { engajamento e conhecimento dos gestores das } \\
\text { áreas para efetivar a prática do modelo. }\end{array}$ & $\begin{array}{c}\text { "Como o projeto é grande e } \\
\text { envolve a alta administração, deve } \\
\text { ser tratado com bastante atenção e } \\
\text { no momento as prioridades são } \\
\text { outras" (QT19). }\end{array}$ & 16 \\
\hline $\begin{array}{l}\text { Resistência dos } \\
\text { Servidores }\end{array}$ & $\begin{array}{l}\text { Refere-se aos desafios que os tribunais } \\
\text { encontram em relação à resistência à mudança } \\
\text { dos servidores, em função das dificuldades em } \\
\text { comprometimento, apoio, entendimento, } \\
\text { descrença na utilização do modelo. }\end{array}$ & $\begin{array}{l}\text { "Desafios da resistência à } \\
\text { mudança" (QT2). }\end{array}$ & 10 \\
\hline $\begin{array}{l}\text { Necessidade de } \\
\text { Recursos } \\
\text { tecnológicos } \\
\text { específicos }\end{array}$ & $\begin{array}{l}\text { Refere-se à necessidade de disponibilidade de } \\
\text { sistema informatizado que permita a execução } \\
\text { das etapas da gestão por competências, bem } \\
\text { como o adequado gerenciamento das suas } \\
\text { informações. }\end{array}$ & $\begin{array}{l}\text { "Inexistência de sistema de } \\
\text { informática próprio para registro } \\
\text { e acompanhamento das } \\
\text { informações e do clima da } \\
\text { organização" (QT8). }\end{array}$ & 4 \\
\hline
\end{tabular}




\begin{tabular}{|c|l|l|c|}
\hline $\begin{array}{c}\text { Desafios } \\
\text { conceituais e } \\
\text { metodológicos do } \\
\text { modelo }\end{array}$ & $\begin{array}{l}\text { Refere-se às dificuldades de aplicação e } \\
\text { desenvolvimento do modelo de gestão por } \\
\text { competências devido à complexidade } \\
\text { conceitual e metodológica do constructo. }\end{array}$ & "Falhas no modelo inicial" (EG1). & $\mathbf{5}$ \\
\hline
\end{tabular}

Fonte: Dados da pesquisa.

Pode-se observar que a principal barreira para implantação da gestão por competências na Justiça Eleitoral se refere a falta de suporte da alta administração e dos gestores das áreas com 16 relatos (em mais da metade dos Tribunais). Este resultado está alinhado com o que foi identificado por Landfeldt e Odelius (2017); Cortês e Meneses (2019); e Montezano, Medeiros, Pinheiro e Oliveira (2019). Apesar de 13 Tribunais terem indi- cado que receberam apoio da alta administração para a implantação (dados quantitativos), alguns deles relataram este ponto como uma dificuldade nas questões abertas, pode ser decorrente das mudanças de gestão ao longo dos anos, e que somente quanto tiveram o apoio da alta administração foi possível efetivar a implementação do modelo. Também corrobora com o estudo de Henklain, et al. (2016) quanto à dificuldade de implementar em função do desconhecimento dos gestores sobre os ganhos com o modelo, o que gera a falta de apoio dos mes- mos e a dificuldade de implementar por falta de preparo técnico também. A resistência dos próprios servidores para implantar o modelo, foi o segundo aspecto mais relatado (10 Tribunais), em função do receio da mudança organizacional, como apontado por Silva et al. (2013); Lucas (2015) e Henklain, et al. (2016). As duas principais limitações estão relacionadas a aspectos do próprio indivíduo e não da organização, o que remete a necessidade de preparar o servidor público para superação destas barreiras.

Em seguida, tem-se as limitações organizacionais, sendo as mais recorrentes relacionadas aos desafios estruturais e aos aspectos culturais do serviço público, com nove e sete relatos respectivamente. O aspecto cultural também foi relatado como impedimento para a adoção do modelo de gestão por competência por estudos identificados na literatura (MUNCK; MUNCK; BORIM-DE-SOUZA, 2011; MUNCK; GALLELI; SOUZA, 2014; LUCAS, 2015; CORTÊS; MENESES, 2019; MONTEZANO; MEDEIROS; PINHEIRO; OLIVEIRA, 2019), divergindo do que foi apontado por Campion et al. (2019) ao considerar a cultura como uma premissa para efetiva adoção, e com isso também acaba gerando a dificuldade de propiciar mudanças na própria cultura. Já a categoria dos aspectos estruturais corrobora com o estudo de Landfeldt e Odelius (2017) e Montezano, Medeiros, Pinheiro e Oliveira (2019), no que tange a ausência de recursos materiais, de pessoal. E ainda, Landfeldt e Odelius (2017) também apontaram limitações de sistemas, o qual relaciona-se à categoria de necessidade e recursos tecnológicos específicos.

Fevorini, Silva e Crepaldi (2014) afirmam que é importante a inserção do conceito de competências a todos, como foi constatado no Caderno de Orientações do TSE sobre a gestão por competências (2013), e foi identificada categoria dos desafios conceituais e metodológicos, assim como apontada a limitação destes aspectos por Montezano Medeiros, Pinheiro e Oliveira (2019).

De um modo geral, pode-se afirmar que as dificuldades encontradas nesta pesquisa estão alinhadas a achados de outros estudos. No entanto, ressalta-se a contribuição de terem sido identificadas maior diversidade de limitações em um mesmo contexto organizacional, diferente dos demais estudos que identificaram alguns pontos específicos, excetuando a pesquisa de Landfeldt e Odelius (2017) que possui resultados mais completos como deste artigo, e a consolidação da produção científica sobre gestão por competências feita por Montezano, Medeiros, Isidro-Filho e Petry (2019).

A identificação das dificuldades permitiu a reflexão acerca de aspectos que precisam ser avaliados para aperfeiçoamento da gestão por competências, conforme estabelecido em Brasil (2013). Portanto, para superar estas dificuldades, buscou-se identificar ações sugeridas para efetiva implementação na Justiça Eleitoral, considerando a realidade específica dos Tribunais. Foram elencados 41 relatos, os quais foram categorizados em cinco temas, conforme apresentado no Quadro 7.

Quadro 7- Ações necessárias para efetiva implantação do modelo de gestão por competência na Justiça Eleitoral

\begin{tabular}{|c|c|c|c|}
\hline Categoria & Descrição & Exemplos de relatos & $\begin{array}{c}\text { Qtd. de } \\
\text { relatos }\end{array}$ \\
\hline
\end{tabular}




\begin{tabular}{|c|c|c|c|}
\hline $\begin{array}{l}\text { Melhoria no suporte } \\
\text { tecnológico para } \\
\text { Gestão por } \\
\text { competências }\end{array}$ & $\begin{array}{l}\text { Refere-se à } \\
\text { desenvolvimento } \\
\text { informatizados específicos à gestão por } \\
\text { competências. }\end{array}$ & $\begin{array}{l}\text { "A implantação de um sistema } \\
\text { informatizado adequado" (QT6). }\end{array}$ & 5 \\
\hline $\begin{array}{l}\text { Comprometimento } \\
\text { da alta administração e } \\
\text { de gestores }\end{array}$ & $\begin{array}{l}\text { Refere-se à necessidade de engajamento } \\
\text { da alta administração e dos gestores das } \\
\text { áreas para viabilizar o apoio efetivo da } \\
\text { implantação da gestão por competências. }\end{array}$ & $\begin{array}{c}\text { "Envolvimento efetivo da Alta } \\
\text { Direção" (EG2). }\end{array}$ & 7 \\
\hline $\begin{array}{l}\text { Disseminação do } \\
\text { modelo de gestão por } \\
\text { competência }\end{array}$ & $\begin{array}{l}\text { Refere-se à aplicação de estratégias de } \\
\text { comunicação interna para esclarecer o } \\
\text { modelo e os benefícios da gestão por } \\
\text { competências, com vistas à obtenção do } \\
\text { maior empenho e comprometimento dos } \\
\text { profissionais. }\end{array}$ & $\begin{array}{c}\text { "Melhoria do endomarketing do } \\
\text { modelo" (QT1). }\end{array}$ & 8 \\
\hline $\begin{array}{l}\text { Aperfeiçoamento do } \\
\text { modelo de gestão por } \\
\text { competências }\end{array}$ & $\begin{array}{l}\text { Refere-se à revisão de aspectos } \\
\text { metodológicos definidos do modelo de } \\
\text { gestão por competências para direcionar } \\
\text { os servidores à adequada expressão de } \\
\text { competências, bem como a ampliação do } \\
\text { seu uso em todos os subsistemas de } \\
\text { gestão de pessoas e em todas as áreas da } \\
\text { Justiça Eleitoral. }\end{array}$ & $\begin{array}{c}\text { "Há necessidade de revisão do } \\
\text { mapeamento das competências" } \\
\text { (QT8). }\end{array}$ & 15 \\
\hline $\begin{array}{l}\text { Atualizações } \\
\text { normativas }\end{array}$ & $\begin{array}{l}\text { Refere-se à necessidade de emitir } \\
\text { normativos específicos e atualizados } \\
\text { para regulamentar a implementação da } \\
\text { efetiva gestão por competências em } \\
\text { todos os subsistemas de gestão de } \\
\text { pessoas. }\end{array}$ & $\begin{array}{c}\text { "Publicação de norma que } \\
\text { instituísse a G.C. como um } \\
\text { programa permanente do órgão, } \\
\text { evitando assim a descontinuidade do } \\
\text { programa com as mudanças de } \\
\text { gestão" (QT7). }\end{array}$ & 6 \\
\hline
\end{tabular}

Fonte: Dados da pesquisa.

Apesar de a maior dificuldade estar relacionada à falta de apoio da alta administração, dentre os relatos de sugestões de melhoria, a categoria relacionada à necessidade de obtenção do comprometimento da alta administração e gestores é a terceira categoria indicada com sete relatos. Já a dificuldade relativa aos desafios conceituais e metodológicos, que ficou como a penúltima categoria em quantitativo de relatos, é o aspecto que consideram maior necessidade de melhoria nos Tribunais ao se referirem ao aperfeiçoamento do modelo de gestão por competências, com 15 relatos, ou seja, quase todos os Tribunais elencaram respostas relacionadas ao aperfeiçoamento metodológico.

Percebeu-se relação também entre outras sugestões de melhoria com as dificuldades elencadas, tais como: disseminação do modelo de gestão por competências para resistências individuais, apoio da alta administração e gestores para aspectos culturais do serviço público; melhoria no suporte tecnológico para necessidades de recursos tecnológicos específicos; e atualizações normativas para aspectos culturais, desafios estruturais e a própria consolidação para normatização dos desafios conceituais e metodológicos.

\section{Considerações finais}

Esta pesquisa permitiu identificar que a Justiça Eleitoral tem avançado nas iniciativas quanto à implantação da gestão por competências nos seus Tribunais. No entanto, apesar de utilizarem como fonte de consultas as experiências de outros órgãos, inclusive da própria Justiça Eleitoral, as iniciativas são individuais e cada Tribunal está adotando uma classificação da tipologia de competências. Quanto às etapas, possuem semelhanças nas que dizem respeito ao subsistema de Treinamento e Desenvolvimento de Pessoal, mas ainda há limitação quanto a outras práticas de gestão de pessoas por competências (ex: concurso público), bem como necessidades de aper- feiçoamento do uso de determinadas etapas propostas por modelos da literatura para viabilizar o alinhamento organizacional, e assim obter melhores resultados.

De modo geral, observou-se a busca dos Tribunais pelo alinhamento com aspectos definidos pela literatura da área quanto aos aspectos do modelo de gestão por competências. As características do modelo de gestão revelam a necessidade de aprimoramento da aplicação, para acompanhar estrategicamente o desenvolvimento e o aperfeiçoamento da força de trabalho, valorizando suas competências. 
A pesquisa permitiu identificar as dificuldades enfrentadas para implementação do modelo de gestão por competências, bem como os benefícios esperados e já alcançados por Tribunais da Justiça Eleitoral quanto aos ganhos já obtidos com a adoção deste modelo, segundo as percepções dos participantes da pesquisa. Observou-se alinhamento entre essas percepções dos ganhos já obtidos com os possíveis benefícios indicados e alinhados com a literatura, o que já é um avanço para as organizações públicas.

Como limitações da pesquisa teve-se a forma da coleta de dados por questionário eletrônico devido ao fato de alguns Tribunais não conseguirem responder o link, sendo necessário o envio em documento word, a não obtenção do retorno de todos os órgãos eleitorais, para ter um censo da realidade da Justiça Eleitoral. Outro ponto diz respeito ao alinhamento do entendimento de conceitos relacionados à gestão por competências, inclusive do que os respondentes consideram como implantação do modelo, pois apesar de o Tribunal indicar não ter ainda a gestão por competências, informou já ter realizado o mapeamento das competências individuais para as áreas.

Como sugestões específicas para a Justiça Eleitoral, têm-se: (i) a necessidade de revisão das competências nos diferentes níveis de análise, de modo que estejam alinhadas para o alcance dos resultados organizacionais previstos no Planejamento Estratégico; (ii) necessidade de envolver e disseminar o modelo de gestão por competências aos servidores para que tenham ciência e possam efetivamente contribuir com o desenvolvimento e expressão de competências individuais para o bom desempenho no trabalho; (iii) ampliar a utilização das competências identificadas para outros processos de gestão de pessoas, além dos relacionados à capacitação para efetiva adoção ao modelo e viabilização de melhores resultados organizacionais; e (iv) criar grupos de trabalho com representantes de todos os Tribunais Eleitorais para realizar estudo referente à possibilidade de desenvolver modelo geral de gestão por competências para a Justiça Eleitoral e verificar se é possível ter os mesmos grupos de competências, por terem a mesma missão organizacional, com possibilidades de adequações aos seus respectivos contextos organizacionais. Isso poderá contribuir tanto para implantação do modelo nos Tribunais que ainda não adotaram, bem como aprimoramento aos que já possuem iniciativas quanto à sua utilização.

Recomenda-se, também, novos estudos acerca da implantação da gestão por competências na administração pública, para compreender o processo de implantação e sua modelagem, com vistas à disseminação do conhecimento para troca de experiências e contribuição efetiva com a implantação pelos Órgãos Públicos, de modo a obter melhorias na prestação dos serviços, bem como investigar o efeito da adoção deste modelo nos resultados organizacionais. Faz-se necessário investigar a mensuração dos efeitos obtidos com a implantação da gestão por competências nos Órgãos da Administração Pública. E ainda, recomenda-se investigar o efetivo alinhamento entre os diferentes níveis das competências (individuais, de grupo e organizacionais), por meio do uso de pesquisa multinível de competências com diferentes fontes de dados.

\section{Referências}

ARAÚJO JÚNIOR, J. A.; MARTINS, I. Gestão Por Competências na Administração Pública: Uma Análise Bibliométrica a Partir do Decreto Lei 5.707/2006. Revista Eletrônica de Gestão Organizacional, v. 12, n. 2, p. 153-162, 2014.

ASAME, M. E.; WAKRIM, M. Towards a compency model: a review of the literature and the competency standards. Education and Information Technologies, v. 23, p. 225-236, 2018.

AVELINO, G. I.B.; NUNES, S. C.; SARSUR, A. M. Modelo de gestão por competências: a aderência dos gestores para o alcance do desempenho organizacional superior. Economia e Gestão, v. 16, n. 44, p. 24-50, 2016.

BANDEIRA, E. L.; ARRUDA, H. R.; CABRAL, A. C. A.; SANTOS, S. M. Panorama da gestão de pessoas no setor público. Revista Pensamento Contemporâneo em Administração, v. 11, n. 4, p. 86-103, 2017.

BARDIN, L. Análise de conteúdo. São Paulo: Edições 70,2016.

BRANDÃO, H. P. Aprendizagem, Contexto, Competência e Desempenho: um estudo multinível (Tese de doutorado). Universidade de Brasília, Brasília, DF, Brasil, 2009. 
BRANDÃO, H. P.; BAHRY, C. P. Gestão por competências: métodos e técnicas para mapeamento de competências. Revista do Serviço Público, v. 56, n. 2, p. 179-194, 2005.

BRANDÃO, H. P.; GUIMARAES, T. A. Gestão de Competências e Gestão de Desempenho: Tecnologias Distintas ou Instrumentos de um Mesmo Construto? Revista de Administração de Empresas, v. 41, n.1, p. 8-15, 2001.

BRASIL. Tribunal Superior Eleitoral. Gestão por competências na Justiça Eleitoral: segmento competências gerenciais: caderno de orientação .Tribunal Superior Eleitoral - Brasília: Tribunal Superior Eleitoral, B82330. CDD658.3, p.30, 2013. Disponível em: < http://www.tse.jus.br/hotsites/catalogopublicacoes/pdf/gestao-por- competencias-je.pdf $>$.

BRITO, L. M. P.; CARloS, M. da G. O.; AVELINO, F. A. M. Gestão de competências: como os empregados percebem este modelo de gestão. Revista de Ciências da Administração, v. 9, n. 18, p. 56$79,2007$.

CAMPION, M. A.; FINK, A. A.; RUGGEBERG, B. J.; CARR, L.; PHILliPS, G. M.; ODMAN, R. B. Doing competencies well: best practices in competency modeling. Personnel Psychology, v. 64, p. 225262,2011

CAMPION, M. C.; SCHEPKER, D. J.; CAMPION, M. A.; SANCHEZ, J. I. Competency modeling: a theoretical and empirical examination of the strategy dissemination process. Human Resource Management, p. 1-16, 2019, https://doi.org/10.1002/hrm.21994.

CAPUANO, E. A. Gestão por competências no setor público: experiências de países avançados e lições para o Brasil. Revista do Serviço Público, v. 66, n. 3, p. 371-394, 2015.

CARBONE, P. P.; TONET, H. C.; BRUNO, J. R. S.; SILVA, K. I. B. Gestão por competências. Rio de Janeiro, Editora FGV.p. 190, 2016.

CHOUHAN, V. S.; SRIVASTAVA, S. Understanding Competencies and Competency Modeling - A Literature Survey. Journal of Business and Management, v. 16, n. 1, p. 14-22, 2014.

CORTÊS, F. G.; MENESES, P. P. M. Gestão estratégica de pessoas no Legislativo Federal brasileiro: condições para a implamentação. Revista de Administração Pública, v. 53, n. 4, p. 657-686, 2019.

DUTRA, J. S., HIPÓLITO, J. A. M.; SILVA, C. M. Gestão de pessoas por competências: o caso de uma empresa do setor de telecomunicações. Revista de Administração Contemporânea, v. 4, n. 1, p. 161-176, 2000 .

FEVORINI, F. B.; SILVA, R. T.; CREPALDI, A. M. Gestão por competências no setor público: exemplos de organizações que adotaram o modelo. Revista de Carreiras e Pessoas, v. 4, n. 2, p. 128-142, 2014.

GAETA, M.; MARZANO, A.; MIRANDA, S.; SANDKUHL, K. The competence management to improve the learning engagement. Journal of Ambient Intelligence and Humanized Computing, v. 8, p. 405-417, 2017.

GETHA-TAYLOR, H.; BLACKMAR, J.; BORRY, E. L. Are competencies universal or situational? A statelevel investigation of collaborative competencies. Review of public personnel Administration, v. 36, n. 3, p. 306-320, 2016.

GUIMARÃES, T. A. A nova administração pública e a abordagem da competência. Revista de Administração Pública, v. 34, n. 3, p. 125-140, 2000.

GUIMARÃES, T. A.; BRUNO-FARIA, M. de F.; BRANDÃO, H.P. Aspectos Metodológicos do diagnóstico de competências em organizações. In Borges-Andrade, J. E., Abbad, G. S., \& Mourão, L. (Org.) Treinamento, Desenvolvimento e Educação em Organizações e Trabalho: fundamentos para a gestão de pessoas. (pp. 216-230). Porto Alegre: Artmed, 2006. 
HENKLAIN, M. H. O.; TEIXEIRA, R. F.; BASTOS, A. E.; LUKIANOU, V. Obstáculos e benefícios na implantação do modelo de gestão por competências: a percepção de consultores de Recursos Humano. Revista Eletrônica Gestão e Serviços, v. 7, n. 1, p. 1441-1465, 2016.

LANDFELDT, I.M.P.; ODELIUS, C.C. Gestão por Competências em Universidades Públicas Federais. In: VI EnGPR, Curitiba, v.1, n. 6, p.1-8, 2017.

LIMA, D. M. S.; MELO, J. A. M. O modelo de gestão de pessoas por competências em um órgão público federal sobre os fatores que afetam a implantação deste modelo. Revista Gestão Industrial, v. 13, n. 4, p. 26-49, 2017.

LIMA, D.; SILVEIRA, V.; TORRES, T. As Competências Organizacionais e Individuais: Uma perspectiva integrada. Revista Eletrônica FACP, n. 7, p. 48-77, 2015.

LUCAS, F. C. Gestão por competências na Administração Pública: conceito e desafios. Conteúdo Jurídico,Brasília, 2015. Disponível

em: $<$ http://www.conteudojuridico.com.br/?artigos\&ver $=2.53481 \& \mathrm{seo}=1>$.

MONTEZANO, L.; ABBAD, G. S.; FREITAS, P. F. P. Modelagem de competências profissionais de organização pública que atua no ramo de ciências forenses. Encontro da ANPAD, Costa do Sauípe-BA, 2016.

MONTEZANO, L.; MEDEIROS, B. N.; ISIDRO-FILHO, A. S.; PETRY, I. S. Panorama da produção científica da gestão por competências na administração pública brasileira (2008 a 2018). Revista Contabilidade, Gestão e Governança, v. 22, n. 2, p. 280-298, 2019.

MOnTEZANO, L.; Medeiros, B. N.; PINHeIRO, A. O.; OliVEIRA, C. A. A. M. Percepção de servidores de uma organização pública federal quanto à implantação da gestão por competências. Revista Eletrônica Gestão \& Sociedade, v. 13, n. 34, p. 2766-2792, 2019.

MUNCK, L.; GALLELI, B.; BORIM-DE-SOUZA, R. Gestão por Competências na Administração Pública de Portugal: uma análise a partir do ciclo interligado de legitimação e de validação. Revista de Ciências da Administração, v. 16, n. 38, p. 29-46, 2014.

SANTOS, F. A. S. Articulação entre Competências Organizacionais e Individuais em um Órgão do Poder Judiciário. Dissertação de Mestrado em Administração, Universidade de Brasília, p. 205, 2012.

SENA, G. A.; CUNHA, N. R. S. Gestão por competências na Administração Pública Brasileira: uma análise da experiência da Justiça Eleitoral. XXXIX Encontro da ANPAD, Belo Horizonte, 2015.

SILVA, F. M.; MELLO, S. P. T.; TORRES, I. A. C. O que se discute sobre gestão por competências no setor público: um estudo preliminar das construções. Revista de Administração da UFSM, v. 6, n. 4, p. 685-693, 2013.

SKORKOVÁ, Z. Competency models in public sector. Procedia - Social and behavioral Sciences, v. 230, p. 226-234, 2016. 